\title{
INCIDENCE AND CONTROL OF THRIPS ON OUTDOOR LETTUCE AT PUKEKOHE
}

\author{
P.J. WORKMAN ${ }^{1}$, G.P. WALKER ${ }^{1}$ and S. WINKLER ${ }^{2}$ \\ ${ }^{1}$ Crop \& Food Research, Private Bag 92169, Auckland, New Zealand \\ ${ }^{2} 46$ c Hapua Street, Remuera, Auckland 1050, New Zealand \\ Corresponding author: workmanp@crop.cri.nz
}

\begin{abstract}
Western flower thrips and onion thrips were the dominant thrips species on lettuce in 10 field trials undertaken at Pukekohe (South Auckland, New Zealand) between 2002 and 2005. This is the first record of western flower thrips on outdoor lettuce. Intonsa flower thrips was also found in lettuce for the first time. Both flower thrips species are vectors of Tomato spotted wilt virus but this virus was not observed in these trials. Thrips populations peaked in summer (Dec-Feb) with greatest numbers on 4 Feb 2003 (mean of $8 /$ lettuce). The low number of thrips on the lettuce and the low rate of reproduction indicate that lettuce is a poor host plant. Thrips feeding damage was not sufficient for harvested lettuce to be down-graded in any of the trials. Imidacloprid seedling drenches applied to control currant lettuce aphid did not reduce thrips numbers. Methamidophos was the most effective insecticide for control of thrips in lettuce.

Keywords: lettuce, Thrips tabaci, Frankliniella occidentalis, Frankliniella intonsa, western flower thrips, Intonsa flower thrips, onion thrips.
\end{abstract}

\section{INTRODUCTION}

Lettuce growers in the Pukekohe area reported increased thrips populations and damage in lettuce (Lactura sativa) starting in 1998 (H. Young, pers. comm.). In this same period resistance to synthetic pyrethroids was detected in onion thrips, Thrips tabaci (Linderman) (Thysanoptera: Thripidae), in onion crops in Pukekohe (Martin \& Workman 2003). Onion growers extensively used synthetic pyrethroids to control onion thrips and the failure of these insecticides resulted in onion crops with massive thrips populations when crops were lifted prior to harvesting. Lettuce growers reported that onion thrips migrated from the drying onions on to lettuce crops (H. Young, pers. comm.). However, in a trial at the Pukekohe Research Centre (PRC), South Auckland, in 2001, where lettuces were planted adjacent to a maturing onion crop that had high numbers of thrips, only low numbers of thrips were found in the lettuces at harvest (1.7 adult thrips/lettuce plant) (P.J. Workman, unpubl. data). It was concluded from this trial that lettuce was a poor host plant for onion thrips.

In other countries, thrips cause a major problem in lettuce crops, mainly by spreading Tomato spotted wilt virus (TSWV). Although TSWV is present in New Zealand, and onion thrips are known to be vectors of this virus, only occasional outbreaks of this disease have been reported in lettuce crops (Fletcher \& Workman 2003). Western flower thrips (WFT), Frankliniella occidentalis (Pergande) (Thysanoptera: Thripidae) and intonsa flower thrips (IFT), Frankliniella intonsa (Trybom) (Thysanoptera: Thripidae), are also vectors of TSWV.

Research to develop an IPM programme for outdoor lettuce began in 2002 (Walker et al. 2003). From spring 2002 to summer 2005 small plot trials were undertaken at the PRC to study the occurrence and control of lettuce pests in summer, autumn, winter and spring plantings. A major focus in these trials was control of currant lettuce aphid, Nasonovia ribisnigri (Mosely) (Hemiptera: Aphidoidae), which arrived in New Zealand at about this time (Stufkens et al. 2002). This paper reports on thrips populations recorded 
in the untreated control plots in 10 trials from September 2002 to April 2005. In addition, the effectiveness of insecticide treatments specifically aimed at controlling thrips in the summer 2004 trial is presented.

\section{METHODS}

\section{Thrips populations and species identifications}

Ten lettuce field trials were undertaken at PRC quarterly each year from September 2002 to April 2005. The layout of the trials was similar to that for the 2004 summer trial although the number of treatments varied from 1 to 8 . Each plot consisted of 2 beds $(15 \mathrm{~m} \times 1.5 \mathrm{~m})$ with 4 rows of lettuce at $0.5 \mathrm{~m}$ spacing between plants and rows (approximately 280 lettuces/plot). Guard rows between treatments were provided by four rows of lettuce in a single bed.

Total thrips counts in the control treatments in these trials were collated to indicate the seasonal abundance, and a representative sample of thrips was collected into $70 \%$ ethyl alcohol from all treatments for identification in the laboratory. Initially only onion thrips, western flower thrips (WFT), Frankliniella occidentalis and intonsa flower thrips (IFT) were recorded, but after the summer 2004 trial a wider range of thrips was identified.

\section{Control of thrips in outdoor lettuce with insecticides}

A small plot field trial undertaken in summer 2004 (27 January-9 March) at the PRC had five insecticide treatments plus an unsprayed control (Table 1). Methamidophos was the only insecticide specifically aimed at thrips control. The other insecticide treatments were for control of currant lettuce aphid and caterpillar pests, but were also assessed for their impact on thrips populations (Table 1). Each treatment was replicated four times in a randomised layout. The lettuce cultivar was Casino.

On the northern side of the trial, a plot of onions $(8 \times 1.5 \mathrm{~m}$ beds, $60 \mathrm{~m}$ long $)$ was maintained without insecticide treatments.

TABLE 1: Treatments used in the summer 2004 lettuce trial at Pukekohe Research Centre.

\begin{tabular}{|c|c|c|c|}
\hline & $\begin{array}{l}\text { Broad spectrum } \\
\text { insecticide }\end{array}$ & $\begin{array}{l}\text { Selective } \\
\text { insecticide }\end{array}$ & Thrips treatment \\
\hline 29 Jan & endosulfan & & \\
\hline $5 \mathrm{Feb}$ & endosulfan & pirimicarb & methamidophos \\
\hline $12 \mathrm{Feb}$ & endosulfan & pirimicarb & methamidophos \\
\hline $19 \mathrm{Feb}$ & dimethoate & pirimicarb & methamidophos \\
\hline $26 \mathrm{Feb}$ & dimethoate & pymetrozine & methamidophos \\
\hline 4 Mar & lambda cyhalothrin & pymetrozine & methamidophos \\
\hline
\end{tabular}

An imidacloprid (Confidor $350^{\circledast} \mathrm{SC}$ ) treatment was applied as a drench at the commercial nursery $24 \mathrm{~h}$ before planting at a rate of $30 \mathrm{ml}$ of imidacloprid in 3 litres water/1000 seedlings. All of the foliar insecticide treatments (Table 2) were applied topically at a rate of 500 litres/ha with a spray boom $(3 \mathrm{~m})$ with 13 hollow cone nozzles set vertically at $25 \mathrm{~cm}$ spacing at 10 bar pressure. The spray boom was set at $0.7 \mathrm{~m}$ above the crop. Multifilm Extra ${ }^{\circledR}$, a water-soluble spray additive, was applied in all foliar spray treatments at $25 \mathrm{ml} / 100$ litres.

Lettuce seedlings were sampled for thrips prior to transplanting by examining five seedlings from each of the 80 trays (144 seedlings/tray) to investigate whether thrips infestations were originating at the propagation nurseries. Also, thrips flights were monitored with yellow sticky traps on $1 \mathrm{~m}$ stakes placed at the corners of the trial and replaced weekly. Thrips were identified directly on the trap with a binocular microscope or, if necessary, removed with kerosene, cleaned with acetone and mounted on glass slides with PVA mounting fluid and identified using a compound microscope.

The lettuces were monitored weekly by destructively sampling eight plants from each replicate (32 per treatment) and the number of thrips (adults and juvenile) recorded. 
TABLE 2: Application rates for topically applied insecticides (500 litres/ha) used in the summer 2004 lettuce trial at the Pukekohe Research Centre.

\begin{tabular}{llcc}
\hline Common name & Product name & Formulation & $\begin{array}{c}\text { Concentration } \\
\text { (g ai/ha) }\end{array}$ \\
\hline dimethoate & Perfeckthion ${ }^{\circledR}$ & $500 \mathrm{~g} / \mathrm{litre}$ & 320 \\
endosulfan & Thiodan ${ }^{\circledR}$ & $350 \mathrm{~g} / \mathrm{litre}$ & 140 \\
lambda cyhalothrin & Karate Zeon ${ }^{\circledR}$ & $250 \mathrm{~g} / \mathrm{litre}$ & 10 \\
methamidophos & Monitor ${ }^{\circledR}$ & $600 \mathrm{~g} / \mathrm{litre}$ & 600 \\
pirimicarb & Pirimor ${ }^{\circledR}$ & $500 \mathrm{~g} / \mathrm{kg}$ & 125 \\
pymetrozine & Chess ${ }^{\circledR}$ & $500 \mathrm{~g} / \mathrm{kg}$ & 50 \\
\hline
\end{tabular}

\section{Statistical analysis}

Total thrips numbers from the outer, wrapper and heart leaves for each lettuce were averaged over the eight lettuces/replicate. Data were transformed by $\log _{10}(n+0.05)$, which was analysed with REML analysis allowing for different variances for different pesticide treatments. A least significant ratio (lsr) was used to test the significance of different treatments, so that if the ratio of the larger mean to the smaller mean is greater than the lsr then the difference in means is statistically significant.

\section{Seasonal thrips populations}

\section{RESULTS AND DISCUSSION}

Thrips populations in lettuce in the untreated control plots built up slowly in spring, were highest in summer and autumn, and very low in winter (Table 3). The numbers of adult thrips in the lettuces were usually greater than the number of larvae except in the summer 2005 trial when WFT was the dominant thrips species collected from the lettuce. The thrips populations in the summer trials of 2003 and 2005 increased sharply at the beginning of the trial and then declined, while thrips numbers in the summer trial of 2004 remained low and relatively static for the duration of the trial (Fig. 1). The low numbers of larvae and the failure of thrips to increase throughout all the trials indicated that the reproduction rate of thrips in lettuce was very low and that lettuce is a poor host plant for the thrips species present in these trials.

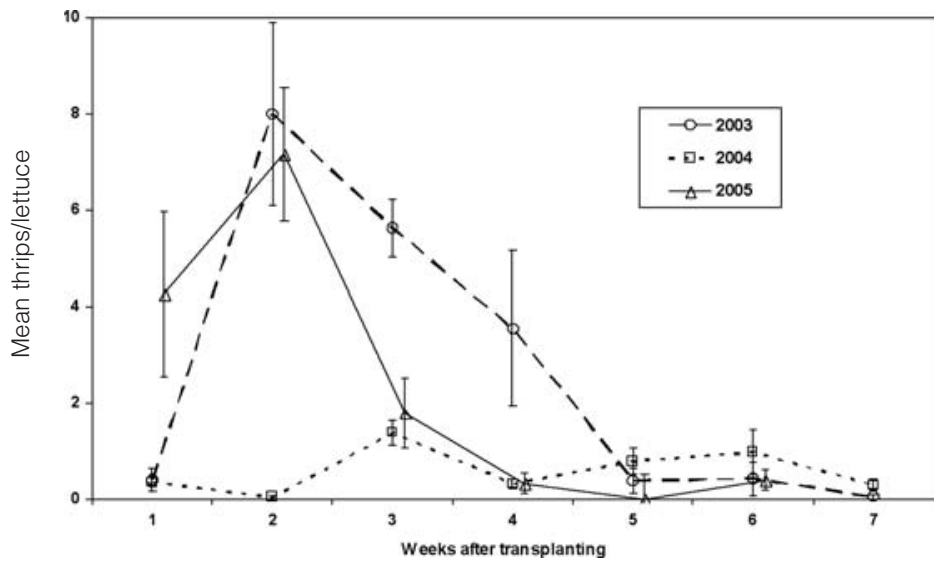

FIGURE 1: The mean number of thrips/lettuce $( \pm S E)$ in untreated control plots for summer trials from 2003 to 2005 at the Pukekohe Research Centre. 
TABLE 3: The mean number of adult and larval thrips/lettuce/number times sampled (SE in brackets) from transplanting until harvest in control plots of 10 lettuce trials at Pukekohe Research Centre from spring 2002 to summer 2005.

\begin{tabular}{lcccc}
\hline & $\begin{array}{c}\text { No. times } \\
\text { sampled }\end{array}$ & $\begin{array}{c}\text { Sampling } \\
\text { intervals }\end{array}$ & Adult thrips & Larval thrips \\
\hline Spring 2002 & 9 & 7 days & $0.03(0.022)$ & 0.00 \\
Spring 2003 & 9 & 7 days & $0.24(0.035)$ & $0.06(0.022)$ \\
Spring 2004 & 4 & 14 days & $0.28(0.202)$ & $0.09(0.047)$ \\
Summer 2003 & 7 & 7 days & $2.26(0.335)$ & $0.37(0.057)$ \\
Summer 2004 & 7 & 7 days & $0.49(0.112)$ & $0.10(0.021)$ \\
Summer 2005 & 6 & 7 days & $0.97(0.186)$ & $1.34(0.328)$ \\
Autumn 2003 & 7 & 14 days & $1.34(0.219)$ & $1.03(0.200)$ \\
Autumn 2004 & 6 & 14 days & $0.27(0.110)$ & $0.06(0.044)$ \\
Winter 2003 & 9 & 14 days & $0.06(0.025)$ & $0.02(0.009)$ \\
Winter 2004 & 6 & 14 days & $0.02(0.016)$ & 0.00 \\
\hline
\end{tabular}

Identification of adult thrips showed that WFT and onion thrips formed a major part of the thrips fauna in lettuce at Pukekohe (Table 4). In fact WFT was often the dominant thrips species and occurred in lettuce throughout the year. This is the first record of WFT in outdoor lettuce in New Zealand. A pesticide-resistant strain of WFT was first detected in New Zealand in 1992 (Martin \& Workman 1994). It is now widespread in greenhouse crops from Northland to Canterbury. WFT has also been observed on lettuce in Christchurch (M.A.W. Stufkens, pers. comm.) but has not been identified in other major lettuce-growing areas, such as Gisborne (P.J. Workman, unpubl. data). Intonsa flower thrips (IFT) was also identified for the first time in lettuce in New Zealand during these trials and was mainly found in summer and autumn (Table 4). IFT was first detected in New Zealand in 2002. While WFT is widely distributed throughout New Zealand, IFT has only been recorded from the Auckland and Waikato regions (Teulon \& Nielsen 2005). Onion thrips mainly occurred in the lettuce trials in spring and summer. Other Thripidae species identified from these lettuce trials include New Zealand flower thrips, Thrips obscuratus (Crawford); white flower thrips, Thrips vulgatissimus (Haliday); chrysanthemum thrips, Thrips nigrophulosus (Uzel); greenhouse thrips, Heliothrips haemorrhoidalis (Bouche); and Anaphothrips dubius (Girault). A predatory thrips, Aeolothrips fasciatus (Linnaeus) (Thysanoptera: Aeolothripidae)), was also identified from these trials.

The summer trial in 2004 was planted adjacent to an onion crop that was not sprayed with insecticides, and therefore contained very high numbers of onion thrips (mean on 6 Jan $2004=632.8$ thrips/onion plant; P.J. Workman, unpubl. data). Higher numbers of onion thrips were consequently found in the lettuce trial in summer 2004 than in the summer trials of 2003 and 2005 (Table 4).

No thrips were found on the lettuce seedlings sampled prior to transplanting the summer 2004 trial. This suggests that the lettuce seedlings were not infested with WFT in the propagation nursery. The numbers of WFT captured on the yellow sticky traps at the corners of the summer trial plot is further evidence that WFT infestation takes place in the field (Fig. 2). Onion thrips was the dominant thrips species caught on the yellow sticky traps, but numbers declined throughout the trial, coinciding with the decline in thrips numbers on the maturing onions in the adjacent onion crop (P.J. Workman, unpubl. data). In contrast, the number of WFT caught on the sticky traps was low throughout the trial. 


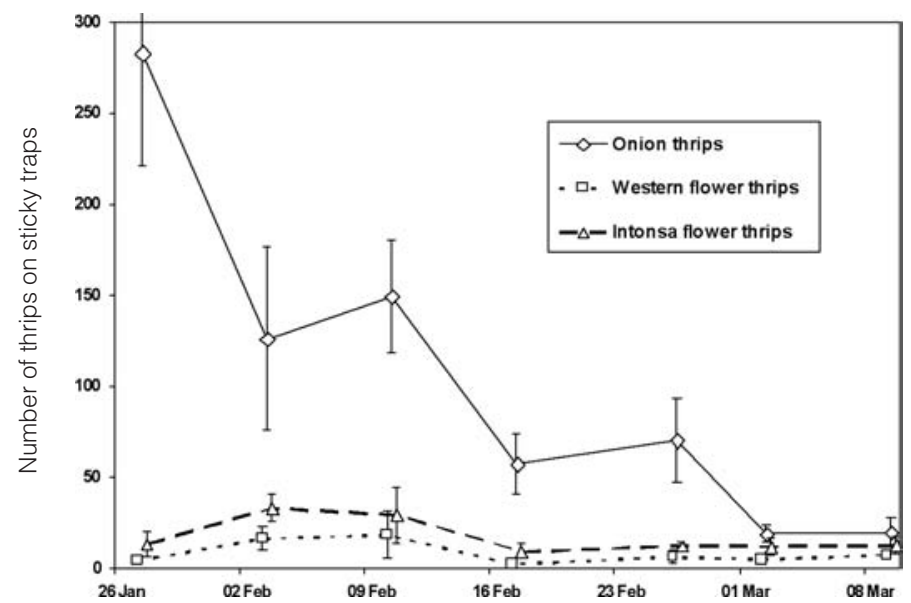

FIGURE 2: Mean numbers of adult onion thrips, western flower thrips and intonsa flower thrips ( \pm SE) from yellow sticky traps during the summer 2004 trial at the Pukekohe Research Centre.

TABLE 4: Total number of adult western flower thrips, onion thrips and intonsa flower thrips identified from the representative collection of thrips from lettuce plants sampled in all plots of 10 lettuce trials at Pukekohe Research Centre from spring 2002 to summer 2005.

\begin{tabular}{lrrrc}
\hline & $\begin{array}{c}\text { Western flower } \\
\text { thrips }\end{array}$ & Onion thrips & $\begin{array}{c}\text { Intonsa flower } \\
\text { thrips }\end{array}$ & $\begin{array}{c}\text { Lettuces } \\
\text { sampled }\end{array}$ \\
\hline Spring 2002 & 10 & 0 & 0 & 1152 \\
Spring 2003 & 111 & 76 & 17 & 1728 \\
Spring 2004 & 10 & 32 & 0 & $100^{1}$ \\
Summer 2003 & 49 & 30 & 7 & 1152 \\
Summer 2004 & 71 & 244 & 27 & 1568 \\
Summer 2005 & 147 & 90 & 56 & 1152 \\
Autumn 2003 & 675 & 17 & 46 & 630 \\
Autumn 2004 & 134 & 5 & 28 & 1152 \\
Winter 2003 & 5 & 0 & 0 & 288 \\
Winter 2004 & 2 & 0 & 0 & 768 \\
\hline
\end{tabular}

${ }^{1}$ Only from thrips collected at the harvest assessment.

The numbers of thrips in the summer 2004 trial were much lower than in the 2003 and 2005 summer trials (Fig. 1) and this may have been because the summer of 2004 was extremely wet (rainfall for duration of trials: $2003-77.8 \mathrm{~mm}, 2004-327 \mathrm{~mm}, 2005$ $92.6 \mathrm{~mm}$ ). Although the number of thrips remained relatively constant throughout the summer 2004 trial, there were three drops in thrips numbers on 3 February, 17 February and 2 March, which corresponded to heavy rainfall events (Fig. 3). 


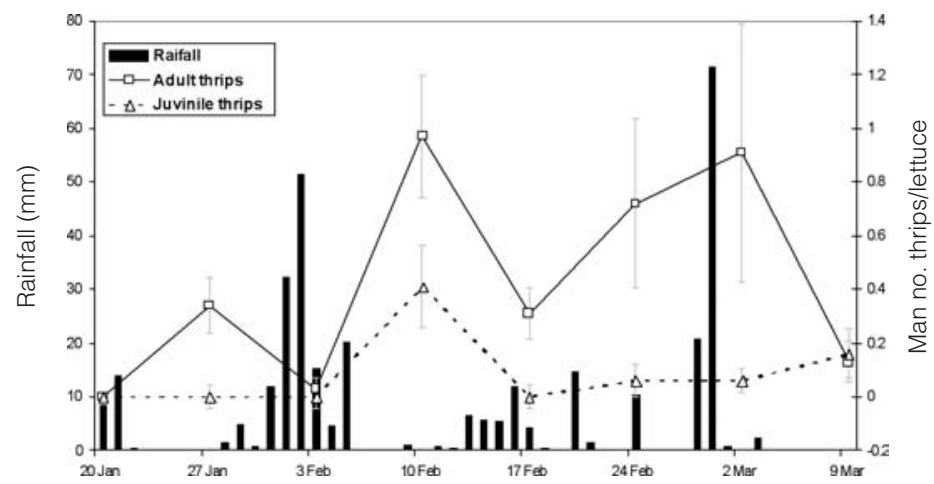

FIGURE 3: Mean number of adult and larval thrips/lettuce $( \pm S E)$ and rainfall data (3 day accumulation in $\mathrm{mm}$ shown as bars) in the summer 2004 trial at the Pukekohe Research Centre.

\section{Control of thrips in outdoor lettuce with insecticides}

In the summer 2004 insecticide trial, the methamidophos treatment had lower populations compared with all other treatments for both adult and larval thrips $(\mathrm{P}<0.05)$ (Table 5). The treatments with weekly applications of either endosulfan, dimethoate or lambda cyhalothrin also had significantly reduced adult and larval thrips numbers compared to the untreated control plots $(\mathrm{P}<0.05)$. As expected, the numbers of adult thrips in the pirimicarb/pymetrozine treatment were similar to those in the control treatment because both of these insecticides are not used to control thrips but it is not known why the numbers of larval thrips were lower than in the control in this treatment $(\mathrm{P}<0.05)$. The imidaclorid drench treatment did not significantly reduce the number of adult thrips but the number of larval thrips was significantly reduced $(\mathrm{P}<0.05)$ compared to the control. Coutts \& Jones (2005) demonstrated that imidacloprid drench treatments applied to lettuce seedlings suppressed the incidence of TSWV by $80-92 \%$, but they did not record the impact on thrips populations in the lettuces. Chaisuekul \& Riley (2001) demonstrated that imidacloprid had an anti-feeding effect on thrips (primarily on WFT) and reduced the number of feeding scars. At present, viruses vectored by thrips are not important in lettuce crops in New Zealand. However, if the incidence of TSWV did increase, imidacloprid may be an important control measure because it also gives good control of aphids on lettuce.

TABLE 5: Back-transformed mean number of adult and larval thrips over the whole trial period/lettuce for the five treatments in the summer 2004 trial at the Pukekohe Research Centre. Least significant ratios are presented and treatments that are significantly different from the control $(\mathbf{P}<0.05)$ are indicated by *.

\begin{tabular}{lcc}
\hline Treatment & Adult & Larvae \\
\hline control & 0.260 & 0.037 \\
imidaclorid & 0.219 & $0.015^{*}$ \\
methamidophos & $0.055^{*}$ & $0.002^{*}$ \\
pirimicarb/pymetrozine & 0.170 & $0.020^{*}$ \\
endosulfan/dimethoate/lamba cyhalothrin & $0.119^{*}$ & $0.005^{*}$ \\
Least significant ratio & 1.735 & 1.374 \\
\hline
\end{tabular}




\section{Thrips damage to lettuce}

Feeding damage by thrips was observed on the lettuce seedlings in summer and autumn when thrips numbers were high, but no significant thrips damage was observed in any of the trials at harvest. Onion thrips, WFT and IFT are all vectors of TSWV, but the flower thrips species are especially associated with the spread of this disease. Inoue et al. (2004) reported that WFT and IFT had a higher rate of accumulation and transmission of TSWV than species from the Thrips genus, including onion thrips. In those trials the transmission rate for the flower thrips species was up to $32 \%$ whereas for onion thrips the transmission rate was 8.6\%. Van de Wetering et al. (1999) tested 14 populations of WFT originating from different hosts and countries and found transmission of TSWV varied between 18 and $75 \%$. While it has been recognised for over 40 years that onion thrips can vector TSWV, recent studies have shown that not all onion thrips populations have the ability to spread this virus. Chatzivassiliou et al. (2002) concluded that onion thrips form a complex in terms of host preference, reproductive strategy and the ability to transmit TSWV.

Despite the presence of WFT and IFT in these trials at PRC, no TSWV was detected from lettuce. This is somewhat surprising because the greenhouse strain of WFT was first detected in New Zealand during an investigation of TSWV spread through greenhouse capsicums (N.A. Martin, pers. comm.). A survey of the incidence of viral diseases in lettuce crops throughout New Zealand, including Pukekohe, also failed to find TSWV (Fletcher et al. 2005). Increased incidences of TSWV have been reported in lettuce and other crops after WFT incursions in Hawaii (Cho et al.1998) and Australia (Latham \& Jones 1996).

At present, thrips are considered a minor pest of lettuce and usually require no specific control measures. There is also no evidence that TSWV is currently a problem in lettuce production in New Zealand. However, the discovery of two new thrips species in lettuce (WFT and IFT) that can vector TSWV has increased the risk of this disease. IPM-compatible control strategies for thrips will be needed if there is an increase in the incidence of TSWV.

\section{ACKNOWLEDGEMENT}

We gratefully acknowledge the assistance of Carol Curtis, Frances MacDonald, Sohail Qureshi, Paul Barnett and Lydia Huggard in sampling these trials. Clare Schatzdorfer from Fruitfed Supplies also assisted in sampling. We also thank Eric O'Neil for statistical analysis, John Fletcher for virus identification and Warwick Henshall of HortResearch for rainfall data. Funds for this research were provided by the MAF Sustainable Farming Fund, Horticulture NZ and the other contributors to the IPM for outdoor lettuce project (02/07 and 05/059), and the New Zealand Foundation for Research, Science and Technology.

\section{REFERENCES}

Chaisuekul C, Riley DG 2001. Thrips (Thysanoptera: Tripidae) feeding damage response to concentrations of imidacloprid in tomato leaf tissue. Journal of Entomological Science 36 (3): 315-317.

Chatzivassiliou EK, Peters D, Katis NI 2002. The efficiency by which Thrips tabaci populations transmit Tomato spotted wilt virus depends on their host preference and reproductive strategy. Phytopathology 92 (6): 603-609.

Cho JJ, Mau RFL, German TL, Hartmann RW, Yudin LS, Gonsalves D, Provvidenti R 1989. A multi-disciplinary approach to management of tomato spotted wilt virus in Hawaii. Plant Disease 73: 375-383.

Coutts BA, Jones RAC 2005. Suppressing spread of tomato spotted wilt virus by drenching infected sources or healthy recipient plants with neonicotinoid insecticides to control thrips vectors. Annals of Applied Biology 146 (1): 95-103. 
Fletcher J, Workman P 2003. Lettuce crops may be more prone to devastating tomato spotted wilt virus. Grower, December: 19-20.

Fletcher JD, France C, Butler RC 2005. Virus surveys of lettuce crops and management of lettuce big-vein disease in North Island New Zealand. New Zealand Plant Protection 58: 239-244.

Inoue T, Sakurai T, Murai T, Maeda T 2004. Specificity of accumulation and transmission of tomato spotted wilt virus (TSWV) in two genera, Frankliniella and Thrips (Thysanoptera: Thripidae). Bulletin of Entomological Research 94 (6): 501-507.

Latham LJ, Jones RAC 1996. Tomato spotted wilt virus and its management. Western Australian Journal of Agricultural, Fourth Series 37: 86-91.

Martin NA, Workman PJ 1994. Confirmation of a pesticide resistant strain of western flower thrips in New Zealand. Proceedings of the 47th New Zealand Plant Protection Conference: 144-148.

Martin NA, Workman PJ 2003. Insecticide resistance in onion thrips (Thrips tabaci) (Thysanoptera: Thripidae). New Zealand Journal of Crop and Horticulture Science 31: 99-106.

Steiner M 2002. Progress towards integrated pest management for thrips (Thysanoptera: Thripidae) in strawberries in Australia. Proceedings of the joint IOBC/WPRS Working Group "Integrated Control in Protected Crops, Temperate Climate" and IOBC/NRS "Greenhouse, Nursery, \& Ornamental Landscape IPM Working Group" at Victoria, British Columbia, Canada, 6-9 May 2002. Bulletin OILB/SROP 25 (1): 253-256.

Stufkens MAW, Teulon DAJ, Bulman SR 2002. Nasonovia ribisnigri a new aphid pest on lettuces (Lactuca sativa L.) and Ribes spp. in Canterbury. New Zealand Plant Protection 55: 437.

Teulon DAJ, Nielsen M-C 2005. Distribution of western (glasshouse strain) and intonsa flower thrips in New Zealand. New Zealand Plant Protection 58: 208-212.

Walker G, Workman P, Stufkens M, Fletcher J, Qurehi S, MacDonald F 2003. IPM for outdoor lettuce. Grower, December: 21-24.

Workman PJ, Martin NA 2002. Towards integrated pest management of Thrips tabaci on onions. New Zealand Plant Protection 55: 188-192.

Van de Wetering F, van der Hoek M, Goldbach R, Mollema C, Peters D 1999. Variation in topovirus transmittion between populations of Frankliniella occidentalis (Thysanoptera: Thripidea). Bulletin of Entomological Research 89 (6): 579-588. 